\title{
The Quest for Heroism: Flaws, Obstacles and Consequences in Chinua Achebe's Things Fall Apart (1958)
}

\author{
Babacar Diakhaté*
}

Laboratoire d'Études africaines et postcoloniales, Université Cheikh Anta Diop Dakar, Sénégal

DOI: $10.36347 /$ sjahss.2021.v09i01.002

| Received: 09.01.2021 | Accepted: 20.01.2021 | Published: 22.01.2021

*Corresponding author: Babacar Diakhaté

Abstract

Some Euro-centric writers such as Joseph Conrad and Joyce Cary considered African people as savages respectively in Heart of Darkness and Mister Johnson. Chinua Achebe published Things Fall Apart (1958) to tell about Africa and African cultures and civilization. This article pinpoints the attitudes of Okonkwo who stands as a hero who is in quest for personal achievements. However, in his struggle against colonization, Okonkwo makes many flaws and encounters obstacles that lead him to fail. This failure facilitates the settlement of colonial schools in the Umuofia. Hence the shift of the children from their traditional beliefs to the new religion.

Keywords: Heroism, Flaws, Missionary Schools, Failure, Colonization.

Copyright $\odot 2021$ The Author(s): This is an open-access article distributed under the terms of the Creative Commons Attribution 4.0 International License (CC BY-NC 4.0) which permits unrestricted use, distribution, and reproduction in any medium for non-commercial use provided the original author and source are credited.

\section{INTRODUCTION}

Many Euro-Centric writers considered the African continent as a tabula Rasa where the people were voided of culture and civilization. In 1958, Chinua Achebe released Things Fall Apart in order to write back to such as Joseph Conrad's Heart of Darkness (1885) [1] and Joyce Cary's Mister Johnson (1939) [2]. These European writers portray Africans as primitive and mindless savages. In Things Fall Apart, Achebe depicts objectively the Igbo society. Through his protagonist, Okonkwo, he shows an African hero who is caught between two cultures. On the one hand, he is committed to perpetuating the cultural tradition of his clan. On the other hand, he leads a struggle against European intruders into his community.

This article aims to demonstrate whether Okonkwo can prevent Europeans from achieving their mission of colonization in Africa. It also displays the strategies of both sides: Okonkwo who defends his clan against colonization and the white man's methods to achieve his aim. The first part focuses on Okonkwo and his heroic attitudes in his community. The second section emphasizes on Okonkow's flaws and obstacles that lead him to fail. The last part shows the consequences of the hero's failure in his clan.

\section{Heroism and Achievements}

The achievement of heroism is very difficult in the Igbo society. In Things Fall Apart Okonkwo's success earns him the respect and honor of the elders. After defeating Amalinze, the cat, he proclaims the greatest wrestler in Umuofia and Mbaino. He demonstrates exceptional skills as the warrior of the village. He brings home five heads during inter-tribal war. Achebe portrays Okonkwo as a man with "incredible prowess". He is very passionate to conquer and destroy his enemies. He is a successful farmer and he gets married with three wives. His wives and sons are afraid of him. He is very proud of his son Nwoye who grumbles a woman. He says:" No matter how prosperous a man was, if he was unable to rule his women and children (and especially his women) he was not really a man [3]. Okonkwo is expected to wipe out his father's reputation. He is strongly motivated to avoid failure.

In the Igbo society, having many wives symbolizes the man's strength and wealth. Through hard work and commitment, he becomes respected and successful. Unoka, Okonkwo's father, is very poor and is used to borrowing money. He thinks that the bad image of his father in the clan may smear on his reputation. Achebe writes: a man was judged according to his worth and not the worth of his father [3]. Okonkwo's father enjoys idleness. He was lazy and 
improvident and was quite incapable of thinking about tomorrow [3].

In Chaka, Thomas Mofolo addresses commitment, determination and a strong desire to success. Chaka achieves heroism when he saves his whole community from the wild beasts that attack people and make victims:

Chaka stabbed it behind the shoulder with his spear, so that when it reached the ground, it fell-a mighty fall. While it was dying, its roars were terrible to hear. Chaka looked at it without hear: it did not seem as if he was looking at a deadly beast of prey which had just attacked him [4].

Chaka is famous for this courageous event in the zuzuland. He becomes an outstanding figure for bringing peace to his people. After killing the beast that used to hunt his community, Chaka stops Zwide's army that was also a threat for his people: "it was on this day that Chaka's hand was blistered with killing. Zwide was taken alive and brought to dinguiwayo [4]. Chika shows exceptional skill as far as war is concerned. His courage and determination make him a great warrior. Therefore, he achieves heroism.

Okonkwo's father is an obstacle to his quest for heroism. He likes song, dance and drinking palm to avoid responsibilities. He never goes to yam field. Okonkwo's father has never worn a title in Umuofia. Achebe remarks: "His fame rested on solid personal achievements" "he had no patience with successful men". "His whole life was dominated by fear, the fear of failure and of weakness" [3]. Unlike his father Unoka, Okonkwo is the first man to bring home a human head.

\section{Obstacles and Flaws}

Okonkwo is expected to overcome many obstacles to reach heroism. In the Umuofia people a person must have a good reputation and a good relationship with all the members of the clan. Okonkwo has to be submissive to the council of elders. But such a thing never happens. The typical example is when the priestess of Agbala comes to take Ezinma, Okonwo's daughter for Agbala's blessing. Okonkwo resists and disturbs the social order. He considers the Agbala's priestess' arrival as an intrusion. The priestess warns him: "beware Okonkwo, beware of exchanging words with Agbala". "Does a man speak when a god speaks? Beware! [3]. The priestess takes Eziinma to the Oracle of the Hills and Caves.

Even Obierika disapproves of Okonkwo's resistance against the laws of his society. Indeed, Okonkwo displays the lack of objectivity between personal values and the public expectations. Okonkwo's main flaw is his stubborn inflexibility. Many observers do not find Okonwko's stubborn attitude interesting.
According to them, he does not need to wipe out his father's memory.

Okonkwo does not act as his people expected. Firstly, he becomes less and less tolerant towards them. Secondly, he refuses to abide by the law of the society. For instance, he is known to be a hard-working person. The extraordinary thing is he cannot tolerate failure and defeat. He said to a man: "this meeting is for MEN" [3]. The man who had contradicted him had no titles. The whole village blames him for his lack of humility and his harshness towards others. He expresses himself in a rigid and inflexible way. Because of the violation of the law and his toughness towards his people, Okonkwo fails.

Okonkwo commits many flaws in the society. At the funeral of Ogbuefi Ezeudu, Okonkwo's gun accidentally discharges and kills the son of Ezeudu. This is considered as an abomination in the Umuofia.

Therefore, Okonkwo and his family flee the land. He finds refuge in his mother's village, in Mbanta. Okonkwo sees his exile as a training experience. During his exile, he notices that the Mbanta villagers have allowed missionaries to establish Christian churches. He sees the missionaries defying the power of local gods. His downfall symbolizes the collapse of his community. The embodiment of traditional laws and values has become the outcast of the clan. Consequently, all the villagers believe in the supremacy of the missionaries. Hence the beginning of Okonkwo's failure.

In Things Fall Apart, Ikemefuna decides to attend the missionaries' schools. He leaves his father's house to join the Christian church. Okonkwo is furious and disappointed. He tries to get the Mbanta people to chase the missionaries out.

When he returns to his fatherland, he realizes that the missionaries has already penetrated the territory and converted the Umuofia people. They convince, Ogbuefi Udo, one of the greatest persons who has many titles to join the Christianity. The missionaries gain more and more ground in Umuofia. They install their law to judge innocent people. There is also corruption with the advent of the missionaries. Indeed, Nnama gives money to the white man who in turn, gives him the piece of land in Umuofia. Therefore, the things that hold them together fall apart. For, the white man succeeds in dividing the clan. They also establish white government with a court house. Obierika explains:

The white man is very clever, he came quietly and peacefully with his religion; we were amused at his foolishness and allowed him to stay. No he has put a knife on the thing that held us together and we have fallen apart 3]. 
Okonkwo's return to his native land is not as memorable as he wished. He never receives the heroic welcome he dreamed of. He admits "men have unaccountable become soft like woman" (Achebe, 1958: 129). Thus, he wants to fight but Obierika advises him against doing so:

"It is already too late...our men and our own sons have joined the rank of the strangers. They have joined his religion and they help to uphold his government...how do you think we can fight when our own brothers have turned against us?" [3].

Okonkwo leaves and kills himself because of honor. He is so overwhelmed by the cumulative effects of his experiences in his quest for heroism. The only thing to do is to commit suicide. He considers himself as a hero and a hero prefers death to humiliation and dishonor.

\section{Consequences of Okonkwo's Failure}

The village's old people fight the stranger. They hit their brothers who join the white man. They do what their fathers would do. Achebe stages: "men have learned to shoot without missing their mark and I have learned to fly without perching on a wing. We must root out this evil [3]. The new concept of brotherhood is introduced to the village for the first time. The sole concept of brotherhood they know is destined to the people of the same clan. The white man's new strategy and ideology allow the blacks and whites to be brothers. In Things Fall Apart, the missionaries have not only imposed their values and gods. They also belittle the natives' gods and deities: false gods, gods of woods and stones [3]. They portend an obscure ending:

"the evil men and all the heathen who in their blindness bowed to wood and stone(to) be thrown into a fire that burns like palm oil while still promising heaven to good men who worshipped the true god to live forever in his happy kingdom [3].

The missionaries set their own laws and beliefs as opposed to what people used to know. They succeed in setting conflict between those who are deeply embedded in the new western values and those who are still ingrained in their traditional beliefs. They settle a new government that protects the new converts against the non-converts.

\section{The Dislocation of the Clans}

The local populations have an overview of the destruction that the missionaries have carried along. The children pursue the new religion. The members of the clans see their strength disrupting. The division of their community becomes more and more apparent. The parents of twins and Ogbanje children are part and parcel of their own community.

Their sons have gone to other places where their dignity and membership in a community was restored. This allows them to earn back what belongs to them. The white man fights against the clan and the locals. This relationship has its ups and downs and is considered to be more offensive than passive. According to them, the white man wins their brothers and the clan can no longer act like one.

\section{The White Man's Arrival in Africa and his Objectives}

The missionaries came in Africa with a religious agenda on the one hand and colonial education on the other. The schools of missionaries help the populations achieve a higher standards of living. In No Longer at Ease, Obi Okonkwo criticizes the attitudes of some individuals towards colonial education: Education for service, not for white collar job and comfortable salaries. With our great country on the threshold of independence we need men who are prepared to serve her well and truly [3]. In Arrow of God, Ezeulu considers missionaries' schools and western education in Africa as a means to understand the white man's strategies. As Cheikh Hamidou Kane states:" l'apprendre l'art de vaincre sans avoir raison" [5].

\section{Missionaries Schools and Colonial Administration}

Many persons do not send their sons to the white man's school. The Umuofia people are spoilt for choice. On the one hand, they do not want to send their sons to colonial schools because of conservativeness. On the other hand, they know that if their sons do not attend schools, other strangers will come to rule them. They know that the future belongs to those who can read and write. Achebe writes:

The white man built a school and a little hospital in Umuofia. He went from family to family begging people to send their children to his school. But at first they only sent their slaves or sometimes their lazy children. Mr Brown begged and argued and prophesied [3].

Africans were not interested in western education. Thanks to the missionaries' patience and perseverance, many Africans changed their minds. However, In Things Fall Apart, Obierika is among the persons who accuse western education of the debasement of traditional education:

"The white man is very clever, He came quietly and peacefully with his religion. We were amused at his foolishness and allowed him to stay. Now he has won our brothers, and our clan can no longer act like one. He has put a knife on the things that held us together and we have fallen apart" [3]

Obierika's speech is very important. The keystones of this colonial policy were education through mission schools. The missionaries' objectives were to make Africans understand the message of the holy book. In History in Education in Nigeria:

"The primary objective of the early Christian missionaries was to convert the 'heathen' or the benighted Africans to Christianity via education. 
Knowledge of the Bible, the ability to sing hymns and recite catechisms, as well as the ability to communicate both orally and in writing, were considered essential for a good Christian" [6].

Missionaries were only interested in religion. They did not know any local language. The medium of education was English. The parents motivated their children to lean the new concepts such as commerce, civilization, Christianity, etc. The missionaries tried to adapt Christian education to local activities:

The missionaries without exception used the schools as a means of conversation and each found that children were more valuable for this purpose than adults. Though adults were not ignored in their evangelical program. In addition to book learning, vocational training was added to the programme; At Abeokuta, for instance, and later at Ouitsha, Lakoja and Calabar, agriculture, carpentry, brick-laying, engineering etc; were encouraged by the C, M,S (Church Mission School), the Church of Scotland and other missions" [6].

In Things Fall Apart, Mr Brown is one of the missionaries who has a prophetical view on education. He thinks that education shapes the future leaders of the clans. For fear of being governed and ruled by strangers, they send their sons to school. The prophecy of $\mathrm{Mr}$ Brown is an efficient argument. He convinces those who are against sending their children to mission schools. Even though Mr Brown's arguments about mission schools that aims at shaping future leaders, he also persuades the natives to send their children to school for religious purposes:

The earliest Christian missionary school in Nigeria was without any doubt an adjunct of the church. It was a replica of a similar development in Britain during the dark ages. The missionaries had to come with the Latin service book in the one hand and the Latin grammar in the other... [6].

According to Mr Brown, there should be an interpreter and administration clerks to help the White District Commissioners. The missionaries create schools to make Africans discover the Bible. The local authorities consider schools as a means to have good auxiliaries. Achebe tells:

Mr Brown's school produced quick results. A few months in it were enough to make one court messenger or even a court clerk. Those who stayed longer became teachers; and from Umuofia laborers went forth into lord's vineyard. New churches were established in the surrounding villages and a few schools with them. From the very beginning religion and education went hand in hand [3].

\section{CONCLUSION}

In Things Fall Apart, Chinua Achebe writes back to African detractors such as Joseph Conrad and Joyce Cary with their value judgment about Africa. In the novel, he demonstrates that African people act as one. But, since the introduction of European colonizers, everything has collapsed. Despite Okonkwo's efforts, the white man achieves his aim. Okonkwo's fear to fail leads him to lose his struggle against colonization. If some observers defend that Okonkwo's failure is due to the bad reputation of his father that he wants to wipe out. Others, judge that Okonkwo's lack of humility is also among the incentive factors of his failure. The flaws, the obstacles and his displacement between Umuofia and Mbanta facilitate the settlement of the colonizers and the division of his people. Thus, the colonizer puts the knife on the things that held them together and they have fallen apart.

\section{REFERENCES}

1. Conrad J. Heart of Darkness, Reprinted in Peguin Classics (2000). 1885.

2. Cary J. Mister Johnson, New Directions Publishing Corporation (June1080). 1939.

3. Achebe C. Things Fall Apart. Heinemann. 1958.

4. Mofolo T. Chaka, Oxford University Press, Ely House London. 1931.

5. Kane CA. L'Aventure Ambiguë, Christian Bourgois, Paris. 1961.

6. Fafunwa BA. History of Education in Nigeria, London, George Allan \& Urwin, LTD, Ruskin House Museum Street. 1974. 